\title{
TEKNIK PENULISAN MODUL KETERAMPILAN BELAJAR UNTUK MAHASISWA
}

\author{
Suprayekti, Sridadi Suparto, Rina Sukawati, dan Mita Septiani \\ e-mail: theonlymitha@gmail.com \\ Kurikulum dan Teknologi Pendidikan FIP Universitas Negeri Jakarta
}

\begin{abstract}
Abstrak: Untuk mencapai kompetensi lulusan yang diharapkan oleh universitas, mahasiswa dituntut untuk memiliki keterampilan belajar. Untuk meningkatkan keterampilan belajar mahasiswa dapat dilakukan dengan mengembangkan sebuah modul. Penelitian ini bertujuan untuk mendeskripsikan cara mengembangkan modul yang tepat untuk meningkatkan keterampilan belajar mahasiswa. Penelitian ini dilakukan di Fakultas Ilmu Pendidikan UNJ pada bulan Februari hingga November2013. Pengumpulan data dilakukan dengan melakukan observasi, studi dokumentasi, dan menyebarkan kuesioner kepada mahasiswa. Analisis data yang digunakan adalah deskriptif kualitatif. Hasil penelitian menunjukkan bahwa untuk mengmbangkan sebuah modul keterampilan belajar mahasiswa, dilakukan melalui tiga tahapan utama, yaitu: perencanaan, persiapan penulisan, serta penulisan dan penyuntingan.
\end{abstract}

Kata-kata kunci: modul, keterampilan belajar, belajar mandiri.

\section{TECHNICAL OF WRITING LEARNING SKILLS MODULE FOR STUDENTS}

Abstract: To gain the graduate competence successfully, the university students need to have learning skills. Assisting the students to have the learning skills can be done by providing them with an appropriate module. This research was intended to identify the procedure of developing the module and produce the module which the students can use dependently to improve their learning skills. The research was conducted at the School of Education, State University of Jakarta. as from February through April 2013. The data to be analyzed descriptively were collected by studying the relevant documents, observation, and distributing questionairs to the students. The research found out three phases in producing the module: planning, writing preparation, and writing and editing. Besides, the research produced a the module for learning skills.

Keywords: module, learning skills, dependent learning

\section{PENDAHULUAN}

Kualitas Sumber Daya Manusia (SDM) Indonesia di mata dunia, menurut data dari Human Development Indeks tahun 2011, Indonesia berada pada peringkat 108 di dunia dari segi kualitas SDM. Bahkan Indonesia berada jauh di bawah Malaysia (peringkat 57), Thailand (peringkat 92), dan Filipina (peringkat 97) (kompasiana, 2011). Dalam globalisasi yang menyangkut hubungan intraregional dan internasional akan terjadi persaingan antarnegara. Indonesia dalam kancah persaingan global menurut World Competitiveness Report menempati urutan ke-45 atau terendah dari seluruh negara yang diteliti, di bawah Singapura (8), Malaysia (34), Cina (35), Filipina (38), dan Thailand (40) (kompasiana, 2011). Masalah daya saing dalam pasar dunia yang semakin terbuka merupakan isu kunci dan tantangan yang tidak ringan. Menurut catatan Direktorat Jenderal Pendidikan Tinggi (Ditjen Dikti) Depdiknas, angka pengangguran sarjana di Indonesia lebih dari 300.000 orang.

Orang tidak bekerja alias pengangguran merupakan masalah bangsa yang tidak pernah selesai. Ada tiga hambatan yang menjadi alasan kenapa orang tidak bekerja, yaitu hambatan kultural, kurikulum sekolah, dan pasar kerja. Hambatan kultural yang dimaksud adalah menyangkut budaya dan etos kerja. Sementara yang menjadi masalah dari kurikulum sekolah adalah belum adanya standar baku kurikulum pembelajaran di sekolah yang mampu menciptakan dan mengembangkan kemandirian SDM yang sesuai dengan kebutuhan dunia kerja. Sedangkan hambatan pasar kerja lebih disebabkan oleh rendahnya kualitas SDM yang ada untuk memenuhi kebutuhan pasar kerja (kompasiana, 2011).

Universitas Negeri Jakarta (UNJ) mengemban fungsi untuk mengembangkan potensi SDM di bidang pendidikan dan nonkependidikan yang mandiri dan memiliki integritas sesuai dengan tuntutan pembangunan yang berkesinambungan. Kompetensi 
lulusan UNJ (2009) antara lain harus memiliki kemampuan professional yang tinggi, kewirausahaan yang professional, kemampuan mengembangkan IPTEK, dan kemampuan untuk meningkatkan kualitas diri, wawasan, dan sikap dalam melaksanakan tugas keprofesionalannya. Untuk mencapai kompetensi lulusan UNJ tersebut, dibutuhkan penguasaan keterampilan belajar. Mahasiswa UNJ harus memiliki keterampilan belajar agar mampu berprestasi dan mampu mengaktualisasikan dirinya secara optimal dalam dunia kerja. Budiarjo (2008) menjelaskan bahwa dengan peserta didik memiliki keterampilan belajar, berarti dapat mempercepat peserta didik untuk belajar, sehingga belajar akan memberi makna pada setiap apa yang sedang peserta didik pelajari. Oleh karena itu, keterampilan belajar memiliki peranan yang penting untuk mencapai proses aktualisasi diri individu di lingkungan masyarakat, sekaligus peserta didik mampu mengembangkan segala potensi pada dirinya, serta dapat memberi makna di setiap apa yang dipelajari peserta didik.

Berdasarkan data empiris mengenai rata-rata Indeks Prestasi Kumulatif (IPK) semester ganjil (083) UNJ tahun 2005-2006, dapat disimpulkan bahwa dari 67 program studi yang ada di UNJ, 53 program studi masih memiliki mahasiswa yang nilai IPK-nya kurang dari 2, sedangkan hanya 14 program studi di UNJ yang nilai IPK mahasiswanya tidak kurang dari 2. Standar nilai minimal IPK 2,50 berdasarkan pada ketetapan nilai IPK dan standar kelulusan (nilai yudisium) di UNJ (2009). Berdasarkan hasil wawancara mahasiswa progam studi teknologi pendidikan angkatan 2007 yang memiliki IPK kurang dari 3 pada tahun pertama perkuliahan, mereka mengalami rendahnya motivasi belajar, kurangnya kemandirian dalam belajar, kurangnya pengetahuan tentang cara belajar efektif dan efisien, serta kurang optimal penerapan keterampilan belajar.

Tantangan-tantangan yang telah dipaparkan di atas disadari sebagai masalah belajar. Ilmu yang mendalami tentang masalah belajar dan pemecahannya adalah Teknologi Pendidikan. Fokus dari teknologi pendidikan (Suparman, 2005) adalah pada proses bagaimana teknologi perangkat lunak dan keras digunakan untuk mengkomunikasikan pengetahuan, keterampilan, atau sikap kepada peserta didik agar mengalami perubahan perilaku seperti yang diharapkan. Maka dari itu, diharapkan melalui pengembangan modul keterampilan belajar ini dapat menjadi sumber belajar mandiri untuk memfasilitasi belajar mahasiswa dalam mengembangkan keterampilan belajar di perguruan tinggi/universitas.
Sitepu (2008) menyebutkan bahwa dalam proses belajar dan membelajarkan, secara rinci sumber belajar dapat berfungsi untuk meningkatkan kualitas proses dan hasil belajar dengan karena sumber belajar dapat mempercepat laju belajar dan membantu pendidik menggunakan waktu secara lebih efisien. Sumber belajar juga berfungsi membina dan mengembangkan gairah peserta didik, sehingga dapat mengurangi beban pendidik dalam menyajikan informasi. Dengan adanya sumber belajar, maka memberikan kemungkinan belajar bersifat lebih individual dengan jalan mengurangi kontrol guru yang kaku dan tradisional, serta memberikan kesempatan kepada peserta didik untuk belajar sesuai dengan kemampuannya. Selain itu, sumber belajar memberikan dasar yang lebih ilmiah dengan jalan merencanakan program pembelajaran yang lebih sistematis serta mengembangkan bahan pembelajaran yang dilandasi penelitian. Sumber belajar menjadikan pembelajaran lebih mantap dengan jalan meningkatkan kemampuan manusia dalam menggunakan berbagai media komunikasi serta penyajian data dan informasi secara lebih konkret (Sitepu, 2008).

Dalam penelitian ini, sumber belajar berfungsi mengurangi beban dosen dalam menyajikan informasi, sehingga dapat lebih banyak membina dan mengembangkan gairah mahasiswa, serta dapat memberikan kemungkinan belajar bersifat lebih individual dengan jalan mengurangi kontrol dosen yang kaku dan tradisional, serta memberikan kesempatan kepada mahasiswa untuk belajar sesuai dengan kemampuannya. Sedangkan sumber belajar mempunyai manfaat untuk memberikan informasi yang akurat, serta memberikan motivasi positif, sehingga mampu merangsang mahasiswa untuk berpikir dan bersikap lebih lanjut.

Seels (2004) menyatakan bahwa pengembangan adalah proses penterjemahan spesifikasi desain ke dalam bentuk fisik. Kawasan pengembangan tidak hanya terdiri dari perangkat keras pembelajaran, melainkan juga perangkat lunaknya, bahan-bahan visual, dan audio, serta program atau paket yang merupakan panduan berbagai bagian Seels (2004). Kawasan pengembangan mencakup fungsi-fungsi desain, produksi, dan penyampaian, sehingga dalam mendesain suatu bahan dapat menggunakan satu jenis teknologi diproduksi dengan menggunakan yang lain, dan disampaikan dengan menggunakan yang lain lagi. Dalam mengembangkan sebuah sumber belajar, ada beberapa tahap yang harus dilakukan. Mengadaptasi dari Depdiknas (2004), Sudrajat mengemukakan prosedur perancangan sumber 
belajar ke dalam enam tahap, yaitu: (1) mempelajari kurikulum, (2) menetapkan kompetensi siswa yang dikehendaki, (3) memilih dan menentukan materi yang akan digunakan, (4) memilih dan menentukan jenis dan sumber belajar, (5) mengembangkan sumber belajar, serta (6) mengevaluasi sumber belajar (akhmadsudrajat.wordpress.com. Terdapat banyak pilihan model pengembangan pembelajaran yang dapat diacu dalam menentukan sumber belajar yang digunakan, dalam penelitian ini digunakan model pengembangan Rowntree. Model pengembangan Rowntree merupakan model pengembangan yang berorientasi pada produk. Model pengembangan ini cocok digunakan untuk membuat sebuah modul maupun bahan ajar konvensional (buku) karena langkah-langkah pada model pengembangan Rowntree dipaparkan secara jelas. Menurut Rowntree, ada tiga langkah yang ditempuh untuk menghasilkan sebuah modul atau bahan ajar konvensional (buku), yaitu: (a) perencanaa, (b) persiapan penulisan, serta (c) penulisan dan penyuntuingan

\section{Perencanaan}

Dalam perencanaan, ada beberapa hal yang perlu diperhatikan yaitu:

a. Profil pemelajar

Langkah pertama yang harus dilakukan dalam mengembangkan sebuah bahan ajar adalah dengan mengidentifikasikan karakteristik peserta didik. Pengetahuan tentang peserta didik meliputi banyak faktor mulai dari usia, lingkungan, gaya belajar, pengetahuan dasar, motivasi belajar, ketertarikan terhadap media tertentu, dan lain-lain. Langkah ini diperlukan agar bahan ajar yang dikembangkan sesuai dengan kebutuhan peserta didik.

\section{b. Menentukan Tujuan Pembelajaran}

Rowntree membedakan tujuan pembelajaran menjadi dua bagian, yaitu aims dan objective. Aim merupakan pernyataan umum tentang apa yang akan dipelajari oleh peserta didik. Dengan kata lain, aim merupakan tujuan umum pembelajaran. Sedangkan Objective merupakan pernyataan spesifik mengenai apa yang dipelajari oleh peserta didik. Dengan kata lain, objective merupakan tujuan pembelajaran khusus. c. Membuat Garis Besar (Outline) Isi Pembelajaran

Setelah menentukan tujuan pembelajaran, maka langkah selanjutnya adalah menganalisis bahan ajar. Dalam menganalisis bahan ajar, yang perlu dilakukan adalah dengan menentukan materi yang sesuai dengan tujuan pembelajaran. Dalam menentukan garis besar isi bahan ajar dapat dilakukan dengan pendekatan subject centre (berorentasi pada mata pelajaran) dan learner centre (berorientasi peserta didik). d. Memilih media penyampaian

Pada langkah ini dilakukan pemilihan media yang akan dikembangkan. Dalam memilih media, ada beberapa faktor yang perlu dipertimbangkan, diantaranya kesesuaian karakteristik peserta didik, tujuan pembelajaran, isi/materi yang disampaikan, biaya, dan lain-lain.

e. Rencanakan pendukung pembelajaran

Dalam mengembangkan sebuah bahan ajar perlu adanya interaksi dengan sumber belajar lainnya. Dengan adanya pendukung pembelajaran, maka dapat memudahkan pemelajar dalam menggunaakan bahan ajar tersebut.

f. Mempertimbangkan bahan ajar yang ada

Hal penting lainnya yang perlu diperhatikan dalam mengembangkan sebuah bahan ajar adalah dengan mempertimbangkan bahan ajar yang ada. Jika bahan ajar yang telah ada tidak sesuai dengan kurikulum atau isi dari bahan ajar tersebut sudah tidak sesuai lagi dengan kebutuhan, maka bahan ajar tersebut perlu disesuaikan. Ini dilakukan agar bahan ajar yang dikembangkan lebih efektif dan efisien.

\section{Persiapan Penulisan}

a. Batasan dan sumber daya

Dalam mengembangkan sebuah bahan ajar, perlu dipertimbangkan batasan dan sumber daya. Selain itu, perlu juga dibuat jadwal kerja untuk memudahkan dalam penyusunan bahan ajar.

b. Mengurutkan gagasan

Membuat urutan kegiatan yang akan dikembangkan di dalam bahan ajar mulai dari awal hingga akhir, dengan demikian akan terlihat jelas apa saja yang ditulis oleh peneliti.

c. Menentukan kegiatan belajar dan umpan balik

Pada tahap ini, pengembang bahan ajar hendaknya merancang kegiatan belajar atau apa yang harus dilakukan peserta didik disertai umpan balik sesuai dengan materi yang disajikan.

d. Tentukan contoh

Pengembang bahan ajar perlu memberikan contoh-contoh dalam penyusunan bahan ajar karena kejelasan materi akan lebih cepat bila dalam uraiannya disertai contoh-contoh.

e. Menentukan gambar atau grafis yang sesuai

Pengembang bahan ajar perlu menampilkan gambar atau grafis yang sesuai untuk mempermudah atau bahkan menarik minat peserta didik terhadap materi yang disajikan.

f. Menentukan perangkat akses

Dalam mengembangkan bahan ajar, pengembang perlu memikirkan perangkat akses dalam bahan ajar agar menjadi mudah dipelajari oleh 
peserta didik. Hal ini dapat dilaksanakan dengan menyusun daftar isi dalam bentuk skema, penomoran yang jelas dan teratur dalam uraian materi, penjelasan penggunaan di bagian pendahuluan, dan sebagainya. g. Menentukan format bahan ajar

Format yang dimaksud di sini adalah bentuk pengemasan bahan ajar. Pengemasan bahan ajar haruslah sederhana dan menarik. Selain itu juga diperhatikan tata letak, warna, huruf yang digunakan, dan sebagainya.

\section{Penulisan dan Penyuntingan}

a. Memulai draf pertama

Pada tahap ini hendaknya menerapkan prinsip reader-friendly. Prinsip reader-friendly adalah prinsip yang mengutamakan pembaca atau peserta didik. Seorang pengembang bahan ajar harus menyesuaikan dengn kondisi peserta didik, seperti pemilihan bahasa, pesan visual, alur penyajian dan seterusnya, sehingga memudahkan pembaca dalam memahami isi materi yang disajikan.

b. Melengkapi dan mengedit draf pertama

Setelah menyusun draf, langkah berikutnya adalah dengan melengkapi draf tersebut hingga selesai. Untuk memperbaikinya, diperlukan bantuan ahli materi agar kesalahan alur yang ada dapat segera diperbaiki.

c. Menuliskan bahan penilaian

Pengembang perlu menuliskan bahan penilaian untuk mengukur kemampuan belajar peserta didik. Tes objektif atau esai dapat diterapkan sesuai dengan kemampuan yang harus dikuasai.

d. Uji coba dan perbaikan

Bahan ajar yang telah dikembangkan perlu diujicobakan kepada peserta didik untuk mengetahui apakah bahan ajar yang dikembangkan telah sesuai dengan harapan.Ada beberapa tahap evaluasi yang dilakukan, diantaranya one-to-one evaluation, small group, dan field test.

Kelebihan dari model ini adalah sederhana dan menjelaskan secara rinci disetiap langkahnya, sehingga memudahkan guru atau dosen dalam menyusun bahan ajar. Namun model ini memiliki kelemahan, yaitu tidak menjelaskan bagaimana proses belajar itu terjadi. Tentunya hal ini dikarenakan model Rowntree hanyalah digunakan untuk menghasilkan sebuah produk atau sesuatu hal, misalnya penulisan bahan ajar konvensional (buku) atau modul.

Mengingat penelitan yang dilakukan bertujuan untuk menghasilkan modul sebagai salah satu sumber belajar yang digunakan dalam pelatihan keterampilan belajar, maka model pengembangan sumber belajar yang sesuai adalah model Rowntree karena model ini menjelaskan secara terperinci tahap demi tahap dalam mengembangkan sebuah bahan ajar konvensional (buku) maupun modul, mulai dari tahap perencanaan, persiapan penulisan hingga uji coba, dan penyuntingan.

Modul pada hakikatnya merupakan media yang dapat disusun dan dipergunakan untuk keperluan pembelajaran konvensional dan keperluan pembelajaran mandiri (Sitepu, 2004). Pemilihan modul cetak sebagai media pembelajaran dianggap perlu karena efektif dan efisien sebagai suatu sistem yang lengkap, berisi rangkaian kegiatan pembelajaran yang dirancang secara sistematis, serta berisi tujuan belajar yang dirumuskan secara jelas dan khusus. Dengan adanya modul keterampilan belajar, diharapkan dapat membantu mahasiswa UNJ dalam mengembangkan keterampilan belajarnya secara mandiri. Fungsi modul adalah bahan ajar yang dinamis karena dapat digunakan untuk belajar mandiri atau pembelajaran konvensional (bersama fasilitator). Modul dapat digunakan dalam setiap proses pembelajaran mulai dari memberi motivasi, memberi informasi, sampai dengan menilai hasil belajar (Belawati, dkk, 2003).

Jika modul dibandingkan dengan buku teks pelajaran, maka perbedaan yang timbul seperti pada tabel 1.

Tabel 1. Perbandingan Modul dengan Buku Teks Pelajaran

\begin{tabular}{|c|c|}
\hline Buku Teks & Modul \\
\hline $\begin{array}{l}\text { Struktur lebih sederhana. Secara } \\
\text { teknis, pendahuluan berisi } \\
\text { penjabaran dari setiap bab, } \\
\text { atau ringkasan dan maksud } \\
\text { jabarannya. }\end{array}$ & $\begin{array}{l}\text { Struktur lebih rinci seperti } \\
\text { dijabarkan tadi, pendahuluan } \\
\text { berisi uraian terkait dengan isi, } \\
\text { tujuan belajar, dan panduan } \\
\text { penggunaan modul. }\end{array}$ \\
\hline $\begin{array}{l}\text { Tidak selalu mencantumkan } \\
\text { tujuan belajar, tes awal atau } \\
\text { akhir, dan komponen lain } \\
\text { seperti modul. }\end{array}$ & $\begin{array}{l}\text { Seluruh komponen sistem } \\
\text { pembelajaran harus ada dalam } \\
\text { modul, termasuk didalamnya } \\
\text { tes hasil belajar, serta tindak } \\
\text { lanjut yang harus dilakukan } \\
\text { oleh pembaca. }\end{array}$ \\
\hline $\begin{array}{l}\text { Materi dijabarkan sesuai dengan } \\
\text { keilmuan yang terkandung } \\
\text { didalamnya. Bahasa yang } \\
\text { digunakan tergantung atas } \\
\text { penulisnya. }\end{array}$ & $\begin{array}{l}\text { Materi disusun berdasarkan } \\
\text { kaidah desain pesan, terdiri } \\
\text { atas pesan verbal dan visual. } \\
\text { Bahasa yang digunakan lebih } \\
\text { sederhana dan komunikatif. }\end{array}$ \\
\hline
\end{tabular}

Dari penjelasan di atas, modul mempunyai beberapa kelebihan dibandingkan dengan buku teks pelajaran. Modul mempunyai struktur lebih rinci, komponen sistem pembelajaran yang lengkap, dan disusun berdasarkan kaidah disain pesan. Dalam penelitian ini, modul memiliki tiga bagian utama yaitu pendahuluan, penyajian, dan bagian penutup. Dalam pengembangan modul keterampilan belajar, peneliti 
akan meumperhatikan dan menggunakan komponenkomponen modul secara utuh, diantaranya bagian pendahuluan (deskripsi singkat, relevansi, dan tujuan pembelajaran), bagian penyajian (judul kegiatan belajar, uraian, contoh atau noncontoh, latihan dan rangkuman), dan bagian penutup (tes formatif, umpan balik, dan tindak lanjut).

\section{Keterampilan Belajar}

Belajar bagaimana belajar berarti peserta didik mampu mengontrol belajar mereka dan mampu menentukan bagaimana berinteraksi dengan lingkungan. Kemampuan demikian menyebabkan proses berpikir seseorang unik serta memampukan peserta didik berpikir kritis dan kreatif. Ia pun berkompetensi dalam memecahkan masalah, mengambil keputusan, dan mengevaluasi kasus (Budiharjo, 2008).

Beberapa keterampilan yang harus dimiliki peserta didik, antara lain: (1) belajar bagaimana menemukan gaya belajar, (2) belajar bagaimana belajar menulis, (3) belajar bagaimana belajar menghafal, dan (4) belajar bagaimana belajar dengan system kredit semester (SKS) (Budiharjo, 2008). Mempelajari cara belajar adalah pengetahuan tentang cara belajar itu sendiri. Aspek-aspek mempelajari cara belajar, antara lain: (1) mempelajari belajar dengan benar, (2) menemukan gaya belajar, (3) mengelola belajar, (4) membaca dan mengingat, (5) mengatur waktu, (6) menjadi unggul di kelas, (7) melakukan penelitian, (8) menyusun karya tulis yang bermutu, dan (9) belajar untuk menghadapi ujian (Fry, 2008). Sedangkan aspekaspek yang mendukung keterampilan belajar, yaitu: (1) Kekuatan AMBAK (Apa Manfaatnya BagiKu?), (2) Lingkungan belajar yang tepat, (3) Memupuk sikap juara, (4) Gaya belajar, (5) Gaya berpikir, (6) Teknik mencatat, (7) Teknik menulis, (8) Meningkatkan daya ingat, (9) Kekuatan membaca, dan (10) Berpikir kreatif (DePorter \& Hernacki, 2008).

Berdasarkan pernyataan di atas dapat disimpulkan bahwa keterampilan belajar adalah proses pengoptimalan belajar dengan didukung oleh aspek-aspek belajar, seperti persiapan belajar (conditioning learning) gaya belajar, gaya berpikir, keterampilan membaca, teknik mencatat, dan keterampilan meningkatkan daya ingat serta membuat jadwal belajar (harian, mingguan dan bulanan), sehingga peserta didik dapat mengembangkan potensi yang ada pada dirinya. Setiap tokoh menyebut keterampilan belajar dengan kata yang berbeda, seperti belajar bagaimana belajar, learning how to learn, dan mempelajari cara belajar. Namun semua kata tersebut memiliki satu makna yang sama, yakni keterampilan belajar.

\section{Penelitian yang Relevan}

Pada tahun 2009, Irma Fitriyani meneliti tentang Pengembangan Paket Pelatihan Keterampilan Belajar bagi Mahasiswa Prodi Teknologi Pendidikan (TP) secara keseluruhan menunjukkan bahwa hasil pengembangan paket pelatihan tersebut mampu meningkatkan keterampilan belajar sekaligus sebagai solusi pemecahan belajar peserta pelatihan.

Penelitian Suprayekti tahun 2010 tentang Keterampilan Belajar Mahasiswa TPUNJ menunjukkan bahwa secara keseluruhan jenis keterampilan belajar telah diterapkan oleh mahasiswa TP UNJ dengan kualitas baik dan kuantitas yang diperoleh secara rata-rata sebesar 74,29. Belajar di perguruan tinggi bagi setiap mahasiswa diarahkan untuk memperoleh kesuksesan studi dalam bentuk indeks prestasi belajar semester dengan kategori sangat baik atau indeks akhir sangat memuaskan. Penelitian tersebut dapat dijadikan sebagai bagian dari studi pendahuluan penelitian ini karena untuk mengembangkan keterampilan belajar secara mandiri, mahasiswa membutuhkan modul keterampilan belajar, agar dapat belajar lebih efektif, efisien, kapan saja, dan di mana saja.

Seperti yang telah diuraikan pada analisis masalah sebelumnya, maka rumusan masalah penelitian ini adalah bagaimana mengembangkan modul belajar mandiri yang dapat meningkatkan keterampilan belajar mahasiswa? Melihat dari perumusan masalah yang ada, maka tujuan yang ingin dicapai penulis dalam penelitian ini adalah cara membuat modul yang tepat untuk meningkatkan keterampilan belajar mahasiswa.

\section{METODE PENELITIAN}

Berdasarkan paradigma yang digunakan, penelitian termasuk ke dalam penelitian kualitatif dengan menggunakan metode deskriptif. Penelitian dilakukan dari bulan Februari hingga November 2013. Dalam mengumpulkan data, digunakan instrumen dokumentasi dan kuesioner. Instrumen dokumentasi yaitu Review penelitian sebelumnya mengenai hasil penelitian "Pengembangan Paket Pelatihan Keterampilan Belajar Bagi Mahasiswa Prodi Teknologi Pendidikan UNJ" oleh Irma Fitriyani (2009) dan Jurnal Ilmiah "Keterampilan Belajar Mahasiswa TP UNJ" oleh Suprayekti (2010). Kuesioner ditujukan kepada 10 orang mahasisiwa tiap jurusan / program studi, dari delapan jurusan / program studi di Fakultas Ilmu Pendidikan Universitas Negeri Jakarta. Analisis data yang digunakan dalam penelitian ini adalah deskriptif kualitatif. 


\section{HASIL DAN PEMBAHASAN}

Dari 120 kuesioner yang disebar ke FIP UNJ, kuesioner yang berhasil terkumpul hanya 92 kuesioner dengan catatan tidak semua kuesioner 8 (delapan) jurusan / program studi terkumpul sebanyak 10 kuesioner sebagai perwakilan. Program studi yang tidak mengumpulkan 10 kuesioner adalah Manajemen Pendidikan (8 kuesioner), PAUD (9 kuesioner), Psikologi Pendidikan (9 kuesioner). Dari hasil isian kuesioner sebanyak 20 pertanyaan yang diisi oleh mahasiswa, dapat disimpulkan sebagai berikut.

1. Mahasiswa yang mengaku sudah mengetahui gaya belajar sebesar $82,22 \%$

2. Mahasiswa memiliki gaya belajar sebagai berikut: (a) melakukan langsung sebesar $48,54 \%$; (b) membaca sebesar 29,13\%; dan (c) mendengarkan sebesar $22,33 \%$.

3. Mahasiswa mempertimbangkan lingkungan belajar dalam mempersiapkan belajar $(95,51 \%)$.

4. Lingkungan belajar yang diharapkan oleh mahasiswa: (a) lingkungan tenang $(51,18 \%)$; (b) kelompok (33,86\%); (c) sendiri (30,71\%); (d) musik (27,56\%); dan (e) dan lain-lain (3,94\%)

5. Mahasiswa memiliki kemampuan mengingat efektif $26,67 \%$

6. Mahasiswa yang membuat jadwal belajar hanya $30 \%$

7. Mahasiswa yang memiliki kemampuan mencatat efektif hanya $32,58 \%$

8. Mahasiswa yang memiliki kemampuan membaca cepat dan efektif hanya $47,13 \%$

9. Mahasiswa yang memiliki kemampuan membuat presentasi hanya $52,81 \%$

10. Mahasiswa yang memahami gaya berpikir sebesar $62,79 \%$.

11. Mahasiswa yang memiliki kesulitan untuk mengakses sumber belajar hanya $23,33 \%$.

12. Mahasiswa yang mengetahui keterampilan belajar hanya $26,19 \%$

13. Mahasiswa yang memiliki kemampuan belajar mandiri 70\%.

14. Mahasiswa yang memiliki motivasi yang kuat untuk belajar mandiri sebesar 87,21.

15. Sebagian besar mahasiswa telah mengetahui tujuan dari kuliah, namun tujuan tersebut masih secara umum, belum spesifik/operasional.

Setelah mengamati data hasil studi pendahuluan dapat disimpulkan bahwa mayoritas mahasiswa belum memiliki keterampilan belajar yang mencakup kemampuan mengingat efektif, membuat jadwal belajar, mencatat efektif, membaca cepat dan efektif, dan merumuskan tujuan kuliah secara spesifik. Untuk menghasilkan sebuah modul yang tepat dalam upaya meningkatkan keterampilan belajar mahasiswa dapat dilakukan langkah-langkah pada Gambar 1.

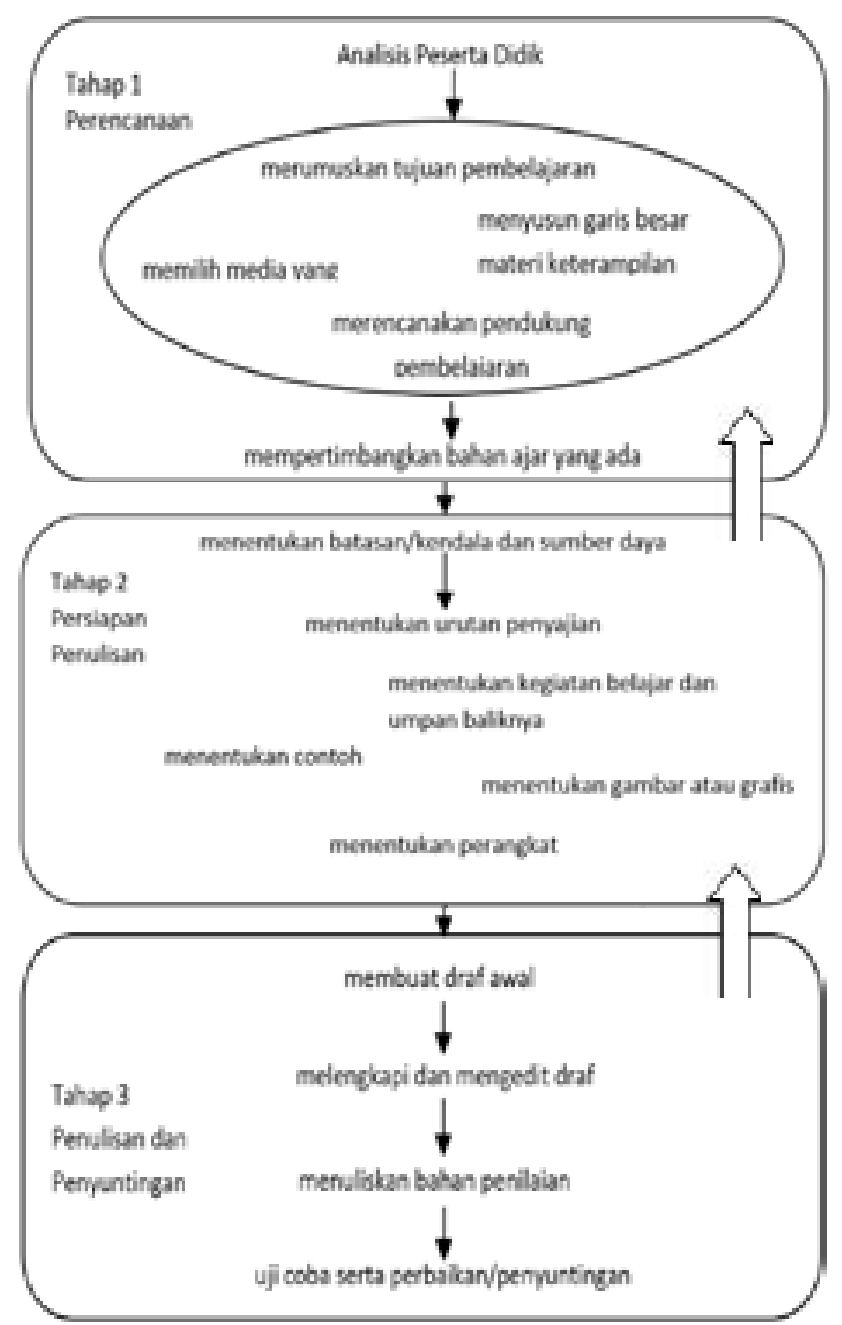

Gambar 1. Pengembangan modul ketrampilan belajar untuk mahasiswa

\section{Proses Pengembangan Modul Keterampilan Belajar Tahap 1 Perencanaan}

1. Analisis Peserta Didik

Mahasiswa FIP UNJ merupakan mahasiswa tingkat awal (tahun ke-1 dan ke-2) yang usianya berkisar 18-22 tahun. Jika dilihat dari usianya, maka dapat dikatakan bahwa mahasiswa tersebut sudah termasuk dalam masa remaja akhir atau masuk ke tahap dewasa awal. Oleh karena itu, pembelajaran yang diberikan haruslah sesuai dengan pendekatan belajar orang dewasa (andragogi).

Dari keterampilan belajar yang ditanyakan dalam kuesioner studi pendahuluan, mahasiswa mengaku ada beberapa keterampilan belajar yang telah dimiliki, dan ada juga dari mereka yang merasa belum memiliki keterampilan tersebut. Jika diurutkan berdasarkan besarnya persentase, maka kemampuan yang masih dirasa dibutuhkan oleh mahasiswa adalah 
sebagai berikut: (1) kemampuan merumuskan tujuan, (2) kemampuan mengingat efektif, (3) kemampuan membuat jadwal belajar, (4) pengetahuan mengenai keterampilan belajar, (5) kemampuan mencatat efektif, dan (6) kemampuan membaca efektif

2. Merumuskan Tujuan Pembelajaran

Berdasarkan analisis peserta didik di atas maka dapat dirumuskan Tujuan Pembelajaran Umum (TPU) dan Tujuan Pembelajaran Khusus (TPK). Secara umum, setelah mempelajari modul keterampilan belajar, mahasiswa akan dapat menerapkan keterampilan belajar secara mandiri dengan benar.Secara khusus, setelah mempelajari modul keterampilan belajar, diharapkan mahasiswa akan dapat: (1) merumuskan tujuan (goal setting) studi di perguruan tinggi, (2) mengelola waktu di perguruan tinggi, (3) menerapkan keterampilan membaca cepat, (4) menerapkan keterampilan mencatat efektif, dan (5) menerapkan keterampilan mengingat efektif dengan skor minimal $80 \%$ benar.

\section{Menyusun Garis Besar Materi Modul}

Materi Modul Keterampilan Belajar berisi lima pokok bahasan yang disajikan dalam peta konsep (mindmapping) pada gambar 2.

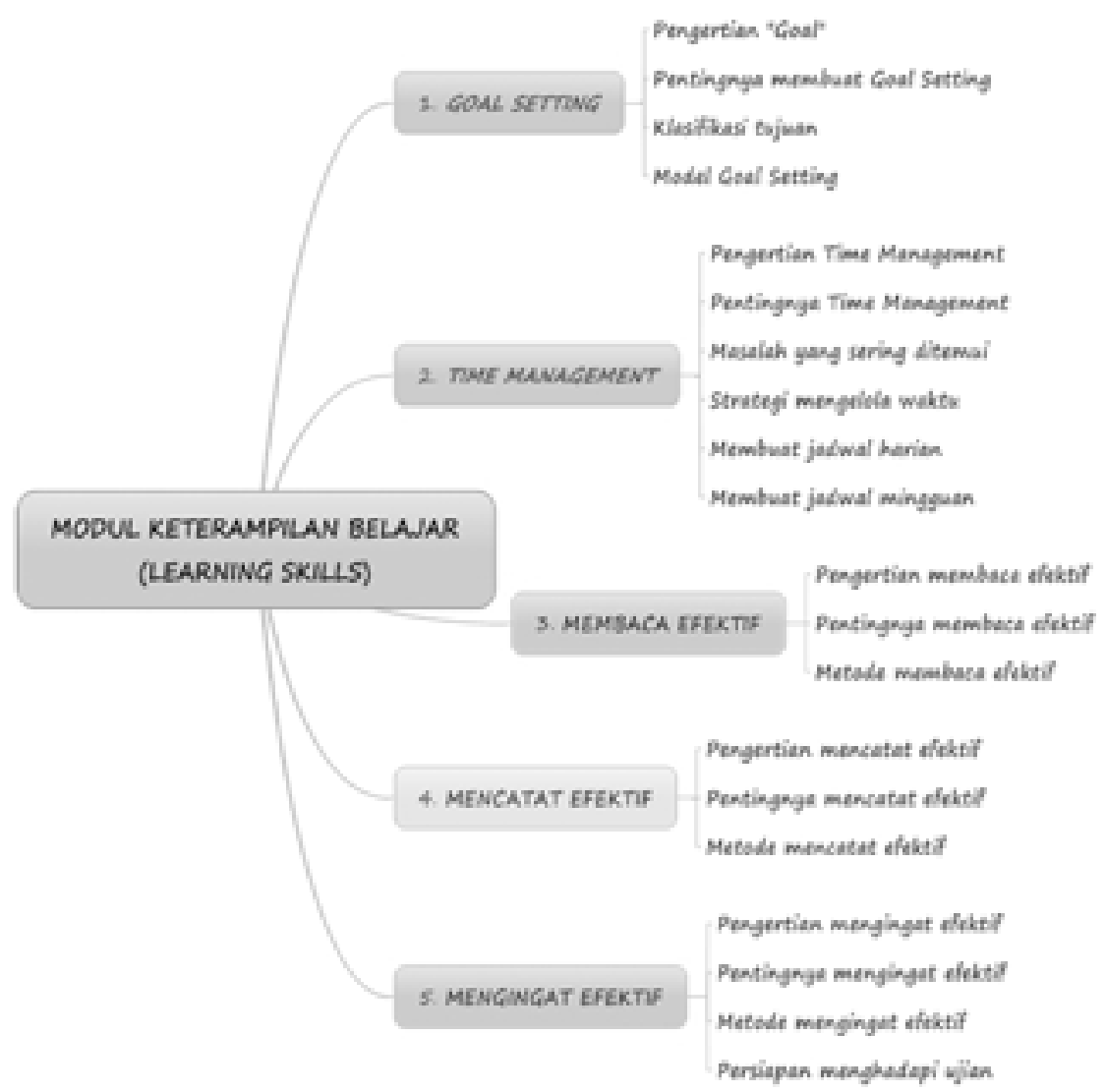

Gambar 3. Peta konsep penyajian modul

\section{Memilih Media yang Tepat}

Berdasarkan penyebaran kuesioner yang dilakukan pada mahasiswa FIP UNJ, sebagian besar mahasiswa $(84,34)$ menyatakan mempunyai kemampuan belajar mandiri dan mayoritas $(87,21 \%)$ menyatakan memiliki motivasi yang kuat untuk belajar mandiri. Untuk itu pemilihan sumber belajar yang bisa digunakan dalam belajar mandiri antara lain adalah modul.

5. Merencanakan Pendukung Pembelajaran

Pemanfaatan modul keterampilan belajar akan lebih optimal bila penggunaannya didampingi oleh fasilitator untuk pengayaan materi dan untuk membantu mahasiswa yang kemampuan belajar mandirinya kurang. Berdasarkan hasil isian kuesioner
92 orang mahasiswa FIP UNJ 15,66\% mahasiswa mengaku tidak memiliki kemampuan untuk belajar mandiri dan 12,79\% mahasiswa mengaku tidak memiliki motivasi yang kuat untuk belajar mandiri. Artinya peran fasilitator sangat penting untuk memfasilitasi mahasiswa yang belum mampu belajar mandiri dan belum memiliki motivasi yang kuat untuk belajar mandiri.

6. Mempertimbangkan Bahan Ajar yang Ada

Sebelumnya bahan ajaryang telah dikembangkan yang terkait keterampilan belajar berupa:

a. Bahan Ajar Keterampilan Belajar yang merupakan bagian dari Pelatihan Keterampilan Belajar yang dikembangkan oleh Irma Fitriani pada tahun 2011. Pemanfaatan bahan ajar keterampilan 
belajar digunakan saat pelatihan di kelas dengan bimbingan dari trainer. Materi yang dikembangkan cukup luas namun kurang mendalam mencakup 10 kompetensi dengan tujuan pembelajaran ranah kognitif C1, C2 dan C3.

b. Pengembangan buku ajar di luar negeri dari berbagai sumber dari universitas di Amerika dan Eropa, juga mengharuskan fasilitator sebagai pendamping untuk memanfaatkan buku ajar tersebut.

c. Selain itu bahan ajar yang ada juga berupa handout pelatihan biasanya dalam bentuk powerpoint, trainer memberikan pelatihan dengan menggunakan presentasi tersebut. Bahan ajar yang dikembangkan biasanya hanya per topik misalkan membaca cepat, mengelola waktu, dan lain sebagainya. Materi yang dikembangkan juga tidak komprehensif karena dibuat per bagian terpisah dan deskripsi materi hanya berupa pointerspointers.

d. Buku bacaan yang ada di pasaran seperti Quantum Learning masih bersifat umum, tidak memiliki tujuan pembelajaran yang spesifik dan terukur. Selain itu isi materi tidak disesuaikan dengan kebutuhan mahasiswa di perguruan tinggi.

\section{Tahap 2 Persiapan Penulisan}

1. Menentukan Batasan / Kendala dan Sumber Daya Ada beberapa batasan dan kendala yang dihadapi oleh penelitian selama proses penelitian ini, antara lain yaitu:

a. Pemilihan modul belajar mandiri sebagai produk pembelajaran yang dikembangkan memiliki konsekuensi pada keluasan dan kedalaman kompetensi / materi keterampilan belajar. Fokus penelitian ini pada pengembangan kompetensi yang bisa dilakukan oleh mahasiswa melalui belajar mandiri, yaitu kompetensi merumuskan tujuan, mengelola waktu, membaca efektif, mencatat efektif, dan mengingat untuk persiapan ujian.

b. Pengembangan kompetensi membaca efektif tidak mengakomodir materi dan latihan membaca cepat karena membutuhkan waktu latihan harian sampai mingguan, serta fasilitator yang bisa memberikan feedback perkembangan mahasiswa. Selain itu, tools software latihan membaca cepat juga dibutuhkan untuk mempermudah latihan.

c. Kenyataannya masih ada kompetensi keterampilan belajar yang dibutuhkan mahasiswa dengan bantuan fasilitator dalam proses pembelajarannya, antara lain kompetensi menulis karya ilmiah (makalah \& skripsi), berpikir kreatif, berpikir kritis, dan memecahkan masalah (problem solving).

d. Kendala SDM yang bukan merupakan desainer grafis / illustrator, sehingga visual modul dengan mencari gambar yang relevan di internet.

e. Kendala pengumpulan kuesioner, tidak semua mahasiswa mengembalikan kuesioner yang diminta. Seharusnya kuesioner yang dikumpulkan sebanyak 10 kuesioner per jurusan / program studi. Jurusan / program studi yang tidak mengembalikan lengkap yaitu Manajemen Pendidikan (8 kuesioner), PAUD (9 kuesioner), Psikologi Pendidikan (9 kuesioner).

2. Menentukan Urutan Penyajian

Adapun urutan penyajian modul terdiri dari tiga bagian yaitu Bagian Awal, Bagian Inti, dan Bagian Akhir. Pada bagia awal terdapat identitas, pengantar, dan pendahuluan modul. Pada bagian inti terdapat penjabaran materi di tiap unitnya. Pada bagian akhir, terdapat daftar pustaka dan kunci jawaban. Untuk lebih jelasnya dapat dilihat pada peta konsep penyajian modul pada Gambar 3.

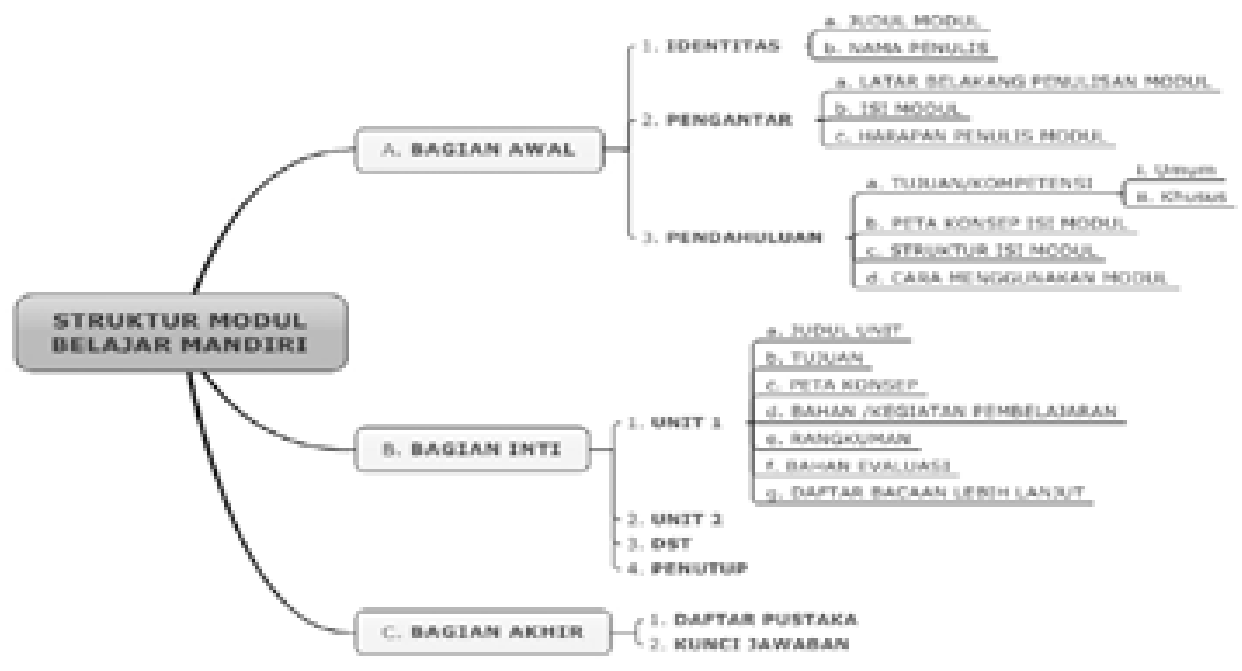

Gambar 3. Peta konsep penyajian modul 
3. Menentukan Kegiatan Belajar dan Umpan Baliknya

Dalam modul ini tipe kegiatan belajar berupa pertanyaan yang beberapa kali diajukan selama materi dipaparkan, sehingga membuat mahasiswa seakanakan berinteraksi dengan penulis modul, dan sejumlah pertanyaan (self-test) berupa pemberian tugas / latihan setelah materi dipaparkan dan tes formatif di akhir unit (pokok bahasan).

\section{Menentukan Contoh}

Penentuan contoh modul keterampilan belajar terdiri dari berbagai bentuk, antara lain berupa analogi, gambar, ilustrasi, mindmapping, tabel / grafik / chart, soal cerita, pendapat dari ahli, dan studi kasus. 5. Menentukan Gambar atau Grafis

Penentuan gambar atau grafis modul tidak dibuat sendiri, tetapi mencari gambar yang relevan di internet.

\section{Menentukan Perangkat Akses}

Perangkat akses merupakan petunjuk penggunaan modul yang bertujuan untuk membantu mahasiswa dalam memanfaatkan modul keterampilan belajar agar mudah dipahami. Petunjuk penggunaan utama modul keterampilan belajar ini diletakkan di awal penulisan modul dan di setiap awal topik pembahasan, sedangkan untuk petunjuk latihan ada di tengah pokok bahasan dan tes formatif ada di akhir pokok pembahasan. Misalnya penempatan di awal dalam bentuk: penjelasan judul, daftar isi. Peta konsep per unit, pendahuluan, keterkaitan dengan materi lain, daftar tujuan, dan petunjuk penggunaan memahami materi. Di bagian tengah bisa berupa pokok pikiran, sistem penomoran, penjelasan tindak lanjut yang harus dilakukan, kesimpulan, dan lain sebagainya. Di bagian akhir bisa berupa kosa kata, post-test, dan index bacaan.

7. Mempertimbangkan Format Penulisan

Pemilihan kertas HVS 80 gram dengan Ukuran B5 karena pertimbangan pengguna mahasiswa yang mobilitasnya tinggi agar modul bisa digunakan kapan saja, dibawa kemana saja, sehingga tidak menyulitkan mahasiswa.

\section{Tahap 3 Penulisan dan Penyuntingan}

\section{Membuat Draft Awal}

Pertama-tama yang harus dilakukan dalam penulisan sebuah modul adalah dengan membuat draf awal. Hasil tulisan ini masih berupa draf yang masih dapat berkembang selama proses penulisan berlangsung.

2. Melengkapi dan mengedit draf.

Setelah selesai membuat draf awal, maka hal selanjutnya yang harus dilakukan adalah melengkapi dan mengedit draf awal tersebut. Hal ini dapat dilakukan dengan cara peer review.

\section{Menuliskan bahan penilaian}

Langkah selanjutnya adalah mempersiapkan bahan penilaian. Bahan penilaian yang dimaksud adalah penilaian yang akan digunakan ketika ujicoba. Bahan penilaian ini bertujuan untuk melihat ketercapaian pengembangan modul.

4. Ujicoba serta perbaikan/penyuntingan

Langkah terakhir dalam mengembangkan sebuah modul keterampilan belajar untuk mahasiswa adalah dengan melakukan ujicoba. Ujicoba ini dilakukan kepada tiga orang ahli (ahli desain pembelajaran, bahasa, dan materi keterampilan belajar) dan mahasiswa sebagai responden (one to one evaluation, small group, dan field trials). Setelah melewati proses tersebut, maka modul sudah dianggap final dan siap untuk digunakan oleh mahasiswa.

\section{PENUTUP}

\section{Kesimpulan}

Keterampilan belajar sangat penting untuk menunjang studi mahasiswa. Namun, masih banyak mahasiswa kesulitan untuk menguasai atau meningkatkan keterampilan belajar. Salah satu solusi untuk meningkatkan keterampilan belajar mahasiswa adalah dengan modul belajar mandiri. Untuk mengembangkan modul untuk meningkatkan keterampilan belajar mahasiswa, ada tiga tahapan utama yang harus dilakukan.

Pertama, tahap perencanaan. Pada tahap ini dilakukan hal-hal berikut: (a) analisis peserta didik, (b) merumuskan tujuan pembelajaran, (c) menyusun garis besar modul, (d) memilih media yang tepat, (e) merencanakan pendukung pembelajaran, dan (f) mempertimbangkan bahan ajar yang ada.

Kedua, tahap persiapan penulisan. Pada tahap persiapan penulisan dilakukan: (a) menentukan batasan/kendala sumber daya, (b) menentukan urutan penyajian, (c) menentukan kegiatan belajar dan umpan baliknya, (d) menentukan contoh, (e) menentukan gambar atau grafis, (f) menentukan perangkat akses, dan (g) mempertimbangkan format penulisat.

Ketiga, tahap penulisan dan penyuntingan. Pada tahap ini diawali dengan membuat draf awal. Setelah draf awal terbentuk, kemudian dilengkapi serta diedit. Selanjutnya, menuliskan bahan pelatihan dan diakhir dengan melakukan ujicoba serta perbaikan/ penyuntingan.

\section{Saran}

Beberapa saran sehubungan dengan proses pengembangan modul Keterampilan Belajar untuk Mahasiswa, diuraikan sebagai berikut. Pertama, sebaiknya setelah modul ini sudah di ujicoba dan di 
revisi, tidak hanya dimanfaatkan untuk mahasiswa FIP UNJ, tetapi untuk mahasiswa UNJ secara keseluruhan, serta universitas lainnya. Kedua, Sebaiknya untuk keterampilan tertentu, misalnya keterampilan membaca efektif perlu pendampingan oleh fasilitator untuk memandu latihan membaca cepat yang membutuhkan waktu harian sampai mingguan. Selain itu, fasilitator juga difasilitasi tools software latihan membaca cepat untuk mempermudah latihan. Ketiga, sebagai tindak lanjut modul perlu ditambah pengayaan dengan pendampingan oleh fasilitator, yaitu pada keterampilan mencatat dan mengingat efektif, karena dibutuhkan latihan dan feedback melalui materi ceramah / presentasi dari dosen. Keempat, perlu dibuat pelatihan khusus untuk kompetensi keterampilan belajar yang memerlukan bantuan fasilitator dalam proses pembelajarannya, antara lain kompetensi menulis karya ilmiah (makalah \& skripsi), berpikir kreatif, berpikir kritis, dan memecahkan masalah (problem solving).

\section{DAFTAR PUSTAKA}

Belawati, T dkk. (2003). Pengembangan bahan ajar. Jakarta: Universitas Negeri Jakarta

Budiarjo, L. (2008). Keterampilan belajar: belajar bagaimana belajar. Yogyakarta: Andi.

Fry, R. (2008). How to study. Diterjemahkan oleh PT. Bhuana Ilmu Populer USA: Career Press

Kompasiana. (2011). Kualitas SDM Indonesia di dunia. Diakses dari http://ekonomi.kompasiana. com/bisnis/2011/03/14/kualitas-sdm-indonesia-di-dunia/ pada tanggal 7 Maret 2012.
Kompasiana. (2011). Tantangan SDM Indonesia di era globalisasi. Diakses dari http://regional.kompasiana.com/2011/06/16/tantangan-sdm-indonesia-di-era-globalisasi/ pada tanggal 7 Maret 2012.

Pusat Komputer UNJ. Rata-rata Indeks Prestasi Kumulatif Semester Ganjil 083 UNJ tahun Angkatan 2005-2006.

Prawiradilaga, D. S. (2006). Penulisan modul untuk pelatihan peneliti. Jakarta: LIPI

Rowntree, D. (1994). Preparing materials for open, distance and flexible learning: An action guide for teachers and trainers. London: Kogan Page.

Seel, B B \& Richey, R C. (2004). Instructional technology: The definition and domains of the field (diterjemahkan oleh Dewi S. Prawiladilaga, Raphael Raharjo dan Yusufhadi Miarso. Jakarta: UNJ.

Sitepu, B P.(2008). Pengembangan Sumber Belajar. Jurnal Pendidikan Penabur - No.11/Tahun ke-7/ Desember 2008

Sitepu, B P. (2004). Penyusunan buku pelajaran. Jakarta: Verbum Publishing.

Sudrajat, A. (2008). Sumber belajar untuk mengefektifkan pembelajaran siswa. Diakses dari http:// akhmadsudrajat.wordpress.com/2008/04/15/ sumber-belajar-untuk-mengefektifkan-pembelajaran-siswa/ diakses pada tanggal 16 April 2011.

Suparman, M.A. (2005). Desain pembelajaran. Jakarta: PAU-PPAI Universitas Terbuka

UNJ. (2009). Buku Pedoman Akademik UNJ 2009/2010. Jakarta: UNJ 